\title{
Defense of Nero in the Style of Seneca and Genre of Biography
}

\author{
Faisal Afridi
}

Numerous scholars have taken the popular stance against Roman emperor Nero's actions. In the style of fictional narrative, this article argues for the defense of Nero against the widely held opinion. The article is written under the guise of Seneca, his tutor and advisor (and later murder victim). It is written in the genre of biography and in the format of a letter addressed to Cassius Dio.

My dear friend Lucius Cassius Dio, how often have I sat at my desk intending to write to you and offer praise for your work on the history of Rome? More times than I can remember. Yet every time I have tried doing so mere words fail me in telling you how your works have affected me. The most recent oration you gave, on the death of Tiberius and the succession of Gaius Caesar, moved me greatly. ${ }^{1}$ How clearly, and without embellishment, you told the tale of those sad times. It takes great skill to make poetry out of simple language, and you, my dear friend, have that skill in such an abundance that even the great Thucydides would burn in envy. The clearness of your argument, the soundness of your reason and the beauty of your language, all are unmatched in anything that I have read before, or can ever hope to read in the future.

Forgive me dear friend, but giving your work the praise it so richly deserves is not the only reason I am writing this letter to you. I am writing this because listening to your recitation on the succession of Caligula, I am struck by the fact that in your works quite soon you will come to the reign of Nero. I grow concerned at how you will treat the successor of Claudius. I trust greatly in your fair-mindedness, but I cannot say the same about the people who have written about Nero in the past. Many lies have been written about the reign of Nero, because of the ease with which one can write slander about an emperor who has been usurped. Too many write ill of men who deserved better, simply because others have written ill of them in the past. Lesser historians, much less talented than yourself, follow the work of historians of the past like sheep following the ones in front, without question as to where they are going or what is the leader's intent. As your fondest of friends, I have taken it upon myself to do all I can to make sure you don't fall into the same trap as the lesser historians before you. In the following passages I have provided a true history of Nero's reign, I have tried to right the wrongs which liars in the past have done to his good name. I have written this with the greatest of hopes that it will help you in your quest to record the true history of Rome. If this gives you even the slightest of help in your quest, I will be overjoyed beyond words.

\footnotetext{
${ }^{1}$ Cassius Dio. "Roman History by Cassius Dio." Penelope uChicago. Trans. Earnest Cary. http://penelope.uchicago. edu/Thayer/E/Roman/Texts/Cassius_Dio/58*.html (accessed 22 December 2015). This refers to Cassius Dio's History of Rome. In Book 58 Dio describes the death of Tiberius.
} 
On the life of Nero much has been written, all of it condemning the Emperor for his gluttony, greed, irresponsibility, blood-thirst, sexual depravity, negligence and imprudence. Men who write about Nero seem to all become the very example of innocence, and lay judgement on Nero as if from some high tower of virtue, condemning Nero as if they themselves have been free from all sin in their own lives. Some brave men, like Petronius and Lucan, hinted criticism at Nero during his own lifetime, but like women speaking shyly from behind a veil on their wedding night, they spoke their valiant condemnations from behind the veil of satire and metaphor. ${ }^{2}$ Other men, like Suetonius and Tacitus, spoke out against Nero, but only to appease the new men who had taken the Emperor's seat and were happy to listen to the mistakes of the past rather than those of the present. $^{3}$

Yet no one has come to Nero's aid, no one has looked at Nero and his life the way it should be looked at, from Nero's eyes. I will present the case for Nero's defense, not judging him from the tower of virtue but looking at him through the eyes of one who has also committed mistakes and done wrongs. I will not avoid the seemingly unjustifiable acts that Nero committed, killing his mother for example, but defend the actions of a man who would commit the worst taboos because his duty forces him to do things which other men must not. A man willing to sacrifice himself to protect that which is more sacred than his most precious possession, a man willing to accept the wrath of the Furies for killing his own mother so that Rome may remain secure, that is true virtue. I hope that you, dear Cassius, will show patience in judging my defense, for it is no easy task fighting against the relish with which people hold on to the condemnations of Nero, and if you do read this with the sense of even-minded fairness that I know is one of your many virtues I hope that by the end some justice may be done for the memory of a righteous man oft condemned.

The first thing critics of Nero use to condemn him is his ancestry. They say, "The Ahenobarbi were a family of men who indulged in ills and had many vices, and Nero shares their vices." In saying this they ignore many of the virtues displayed by the Ahenobarbi family. Nero's father was a despicable man, treacherous and arrogant, but looking back at his family there were examples of virtue too. His great-grandfather, Domitius Gnaeus Ahenobarbus, was a man of great standing, courage, and nobility. He was an outstanding general who commanded a large fleet and was offered a chance to take the place of Mark Antony by Antony's own soldiers, but Domitius showed dignity and resolve in this instance and chose what he thought was right over what was profitable and joined Octavian forces, even though he was ill and dying. ${ }^{4}$ He was an example of Nero's paternal noble lineage. Why is Domitius ignored while worse examples are brought to the fore? You must remember, dear Dio, that the father is not always the most clear example of how the son will behave. Look at the Emperor Caligula's father Germanicus: he was a man of

\footnotetext{
${ }^{2}$ Petronius Arbiter. "The Satyricon, Complete" Gutenberg. Trans. David Widger. http://www.gutenberg.org/files/5225

15225-h/5225-h.htm\#linkVOLUME II (accessed December 22, 2015). Petronius's Satyricon talks about a lavish dinner given by the theatrical Trimalchio, which is considered a veiled attack on Nero's own love of lavishness and acting. Lucan's De Incendio Urbis, a lost work, is said to have implied that Nero started the great fire of Rome.

${ }^{3}$ Suetonius, "Nero," in Lives of the Caesars, by Suetonius, trans. Catharine Edwards (New York: Oxford World's Classics, 2000), 195-227. In Suetonius' Twelve Caesars the attacks on Nero can be construed as being justification for the end of the Julio-Claudian dynasty rule of Rome.

${ }^{4}$ Ibid., 196.
} 
outstanding moral character and courage, he was known as the perfect Roman long after his death, yet his son was the worst of tyrants, hell-bent on committing every single crime a Roman possibly could. Emperor Claudius' father, Drusus, was the picture of courage and led Roman forces as one of the greatest general of the land, yet the son was a cripple. If the son does not necessarily carry the virtues of the father, why then should he carry the vices? It is true a sweet fruit will not grow on a rotten tree, but if a tree is healthy enough to have produced a sweet fruit among bitter ones in the past, why can't it produce another sweet fruit in the future?

On the other hand, Dio, remember that Nero's lineage had two families. If Nero's paternal lineage makes him subject to abusing his position, what of his maternal side? Agrippina was the daughter of Germanicus too, as well as the great-granddaughter of the deified Augustus. Being the descendant of a God, there is no lineage higher than that. Even his adopted father, and her mother's uncle, Claudius, was a good and just ruler, though ridiculed as a cripple. Yet despite her noble lineage, Agrippina was a power hungry, ruthless, and violent woman who would even stoop to committing the sin of incest in order to appease her ambitions. If not even Agrippina's noble lineage could guarantee upstanding character, which lineage can? Even Vulcan, son of Jupiter and Juno, could be lame, while Arachne, daughter of a shepherd, could match the skill Gods. Surely a man as fair-minded as yourself can see that the lineage of a man is without consequence; it is only the man himself who can decide his vices or his virtues. If this is true then, dear Dio, you must not condemn Nero on the strength of his lineage or descent, but judge him for his own strengths and weaknesses. If, on the other hand, you hold to the view that lineage gives a strong indication of character, remember that the tree Nero descends from may often bear bitter fruit, but it occasionally also gives fruit of unmatched sweetness. In either case, Nero is not condemned by his ancestry.

Nero is also often criticized for his interests in theatre and singing, which he is accused of concentrating on rather than conquering more territory and expanding the Empire. Nero is condemned for caring for his voice as well as the arts. To this you must ask, what is wrong with art itself? Some of the greatest works of poetry and literature written were by senators, consuls and other men of high stature. Even his greatest critics, such as Suetonius, concede that Nero was a great artist. ${ }^{5}$ Why then should he not share his talents with the world, as Cicero and Lucan did? Critics of Nero, many of whom dabbled in the arts themselves, hold Nero to rules they themselves don't abide by. When Marcus Aurelius is held up as a bastion among rulers even though he was often busier writing advice rather than ruling the Empire, should Nero's art not also be cherished for the great work it was? Surely there are reasons why these two Emperors concentrated on literature and art while other emperors concentrated solely on ruling Rome?

Marcus Aurelius ruled Rome during a peaceful and prosperous time, during which Rome didn't need a strong hand to guide it. As Tacitus implied, it is in times of peace that certain things flourish while others die down. ${ }^{6}$ Oratorical skill, he said, is less important during times of peace because there is a wise emperor who decides issues in a just and equal fashion. Strong rule

\footnotetext{
${ }^{5}$ Ibid., 204-208.

${ }^{6}$ Tacitus, "Dialogue on Orators," in Ancient Literary Criticism: The Principal Texts in New Translations, ed. Donald Andrew Russell and Michael Winterbottom (Oxford: Oxford University Press, 1972), 458.
} 
guiding the state is not needed either in peaceful times. When a ship is sailing smoothly with the wind, no captain would paddle against it, so when the ship of state is sailing smoothly why would Nero interfere with strong-handed command? On stormy seas the captain will indeed have to force his men to paddle against the current sweeping them away, and to take in the sails so that the stormy wind doesn't blow the ship asunder. In the same way, in times of strife, Rome needs an emperor to command it with a sure hand and absolute control, to fight against the direction the ship of state is sailing. In these times Rome and her Emperor have no time for leisurely pursuits like art and literature. Instead, they must concentrate all their faculties in finding solutions to present problems, and the people of Rome must also concentrate on preservation rather than leisure. However, in peaceful times, men can concentrate on things that they wouldn't have time to ponder on during times of war, like art and literature.

Indeed, these things grow and flourish during such periods. Most of the great Roman art and literature are from periods of peace, for only then is there time for people to enjoy these works, and thus only then is there demand for the crafts of artists and writers. Indeed, during Nero's time the people of Rome flourished in the arts, then why is it wrong for the Emperor to take interest in the arts as well? Nero taking to the arts and literature during a time when interest in it was high in Rome showed that he was indeed privy to the national sentiment of his people. His generous patronage to the arts showed that he was willing to invest in what his people were interested in. That Nero always took an interest in the sentiments of his people is shown in his nightly wandering in the street of Rome, where he mingled with the common people under the guise of an ordinary Roman. ${ }^{7}$ Ulysses when he first got back to Ithaca also, at first, disguised himself as an ordinary man so that he could better understand what had been going on in his kingdom during his absence. In the same way Nero too walked the street of Rome as an ordinary man so he could be in touch with the desires of his people and thus gain a better understanding as to their needs. So why is it that critics of Nero attacked him continuously for concentrating of art rather than rule, whereas critics of someone like Marcus Aurelius rarely attacked him for the same reason? Perhaps it is jealousy that burns the hearts of his critics, they are bitter that a man who is blessed with so much power should also be blessed with more talent in the field of art than they are.

Nero is often criticized for his lack of conquest, for not seeking to expand the Roman empire. But you must ask, did Rome really need more territory so badly? When a man sits to have his breakfast and has had so much to eat that he no longer feels hungry, should he keep eating until he is finally so full that his stomach bursts or till it forces him to vomit his entire meal out, or should he get up and go about his daily business until hunger compels him to have another meal? Of course he should stop when he is no longer hungry. In the same way when Rome was as large as it had become by the time Nero came to the throne, would it really be wise to keep expanding to new territory? The truly wise thing to do would be to try to build the empire that one has in hand into something splendid and, most importantly, to make sure that the state's citizens are happy and satisfied with the Empire. For otherwise the desire for conquest and fresh land would never stop, Rome would keep expanding till her people were exhausted and some Barbarian beat her back to where she started from, as happened to the evil-minded Persians who, consumed with

\footnotetext{
${ }^{7}$ Tacitus, The Annals: The Reigns of Tiberius, Claudius and Nero, trans. J.C. Yardley (New York: Oxford World's Classics, 2008), 282.
} 
greed for land and riches, marched all the way to Greece only to be humiliated and forced to run back like a dog that has just been kicked by its master. There is great virtue in moderation while gluttony only brings misfortune and misery.

Nero understood the benefits of moderation well. Rather than conquering new lands he sought to appease the people and better the empire that he already ruled. He gave a lot of money to the Praetorian Guard. He gave new liberties to the senate. He banned capital punishment. He granted slaves the ability to bring civil lawsuits against their masters. He rebuilt Rome after the Great Fire which ruined it. He gave a lot of wealth to the arts. He engineered a peace with the vile Parthians. He lowered the fee of lawyers. He worked on several charitable projects to ease the suffering of the common people during times of economic hardships. He helped those whose houses had burnt down after the Great Fire. Even one of his foremost critics, Suetonius, can't help but report on these aspects of Nero's rule, commenting on his mercy and charity, all the while condemning Nero. ${ }^{8}$ That even Suetonius would grudgingly report on Nero's righteousness shows how clearly just Nero's rule had been. Such was Nero's caring for his people that he even sought to rid them of all taxation, only to be dissuaded by his wise contemporaries, the same men who were already sharpening the knives they would use to stab him in the back. Critics are quick to point out that Nero's rule became more tyrannical and unjust with time, of course what they ignore is that the times themselves changed rather than Nero. When conspirators, hell-bent on unjustly usurping Nero at all costs, surrounded him on all sides, only then did his just rule became tyrannical as he tried desperately to hold onto the seat that was his rightful place.

Now comes the most heart-wrenching of all occurrences that happened during Nero's reign, the sad decision which no doubt troubled his mind for many years, the decision to kill his mother Agrippina. To kill a parent is without a doubt the most unforgivable of sins, but let us examine the circumstances which forced Nero's hand and made him commit that most horrible of crimes. Many may say that Nero was a cruel and uncaring son, in that they are wrong. On his first day as Emperor, Nero showed his mother proper devotion, giving the tribune of the watch the password "Best of all Mothers", dedicated to Agrippina. He also allowed her to accompany him wherever he went, sharing a litter with her, thus showing her great respect and reverence. Indeed so indulgent was Nero of his mother, that he even often let her sit next to him on the throne, so that Barbarians often saluted Nero and Agrippina as equals, a practice that Nero did not try to stop.

So clearly Nero loved and respected his mother, but how did Agrippina behave towards Nero? The fact is that of all the sources, all comments written on Agrippina, none describe her ever showing any love and respect for her son. Agrippina was a woman of great ambition and thirst for power, even committing incest by marrying her uncle, the Emperor Claudius, in order to obtain power. She had little regard for reciprocating the feelings others had for her; her poisoning of her husband, Claudius, is proof of that. She would stop at nothing to achieve her desire of accumulating influence, even murdering proconsul Julius Silanus out of caution rather than necessity. ${ }^{9}$ It was that desire for power, rather than any filial devotion to her son, that drove her to

\footnotetext{
${ }^{8}$ Suetonius, 199-200.

${ }^{9}$ Tacitus. The Annals, 270.
} 
seize the throne for Nero and she would not tolerate anyone usurping that influence. Even when Nero fell in love with a lowly freedwoman, Acte, what drove Agrippina to oppose this relationship was the feeling that this would lessen her influence over the Emperor.

When someone's lust for power grows beyond their impulse for caution, they will bring about their own downfall. That is what happened to Agrippina; her improper desire to control Rome led to her end. And how wicked was your pursuit for power, O Agrippina! How ungrateful for a woman to abandon the gift of the yarn and spindle Minerva granted to all women, and instead to try and influence the seat that was once occupied by Gods like the Deified Augustus. To think that Rome, a nation founded by the twin descendants of Mars, a nation known for its courage and valour, would be ruled over by a woman! As if Romans were no better than the filthy Egyptians or the Celtic Barbarians! Does a lioness ever gain command over the lion, or an eagless over an eagle? No, Nature would not allow it. So how could Nature ever allow the Lions of Rome to be ruled over by a woman?

Nero grew frustrated with Agrippina's efforts to effectively become the co-empress of Rome. Nero decided to finally check his mother's habit of flaunting her status of power by sitting next to the Emperor, as if they were on equal standing. Nero decided to greet Agrippina as she walked towards him, to make it seem as if she was sitting beside him not purely out of her own volition but by the grace of the Emperor. This, and other such acts by Nero, to lessen the control of Agrippina over Rome sent Agrippina into a rage, she started threatening to force Nero out of his position as Emperor and installing Britannicus instead. ${ }^{10}$ Coming from Agrippina a threat of this nature holds dangerous meaning, she had already killed many people in her quest for power, killing her own son would not be out of the question for a woman like Agrippina. What sort of Emperor would be installed by a woman who would do away with her own son? Agrippina would no doubt install a tyrant into power, for despotic tyrants hold more power over their people than any other kind of emperor.

If Agrippina were to succeed in her endeavour, all the good work Nero had done during his reign would be annulled, and Rome would be driven to despair. No doubt Nero mulled over this problem for days and days before deciding that the only thing that could be done to secure Rome's future was to do away with Agrippina and all other rivals who wanted to be Emperor. The depth of a man's true love for his country can only be judged from what he's willing to sacrifice for it. Nero showed how greatly he loved Rome by sacrificing his own mother for his country, risking the wrath of the Furies as long as the people of Rome would not suffer a terrible fate, that of being ruled by a woman. That he made the right choice was clear from the immediate reaction to the death of Agrippina among the Roman citizens, his decision was praised by the senate as well as the citizenry. Unfortunately, his great sacrifice was not ultimately successful. Conspirators and unfortunate circumstances eventually led to Nero's overthrow and a period of civil war and chaos in Rome. But Dio you must remember that a great act remains great, whether it is successful or not.

Here I must end my letter. I hope this little offering of mine has brought you some kind of instruction dear Dio. I am sure I have cleared up for you the reasons behind some of the rumours,

\footnotetext{
${ }^{10}$ Ibid, 276.
} 
that with vile intent, have been spread about the noble Nero. If you reflect on the passages from the previous section they should help you in explaining the actions that are most often used to damn Nero. I will leave you with a saying that is often recited, though I am not sure who wrote it first, "To truly know a man is to know his sins". Ask yourself this, if a man's most heinous acts are found to be just, are his other acts likely to be unjust? All around us we see men who commit wicked deeds for no reason other than personal benefit, yet they are not condemned. How then can a man who committed his greatest sins for the common good be damned? I am sure a man as fair-minded and noble as you will know that such a man cannot be justly damned.

Farewell. 


\section{Bibliography}

Dio, Cassius. "Roman History by Cassius Dio." Penelope uChicago. Translated by Earnest Cary. http://penelope.uchicago.edu/Thayer/E/Roman/Texts/Cassius Dio/58*html (accessed December 22, 2015).

Petronius. "The Satyricon." Gutenberg.org. Translated by David Widger. http://www.gutenberg. org/files/5225/5225-h/5225-h.htm\#linkVOLUME_II (accessed December 22, 2015).

Suetonius. "Nero." In Lives of the Caesars, by Suetonius, translated by Catharine Edwards, 195-227. New York: Oxford World's Classics, 2000.

Tacitus. The Annals: The Reigns of Tiberius, Claudius and Nero. Translated by J.C. Yardley. Oxford: Oxford University Press, 2008.

Tacitus. "Dialogue on Orators." In Ancient Literary Criticism: The Principal Texts in New Translations, edited by Andrew Donald Russell and Michael Winterbottom, 433-459. Oxford: Oxford University Press, 1972. 